Article

\title{
Structure Elucidation of Procyanidins Isolated from Rhododendron formosanum and Their Anti-Oxidative and Anti-Bacterial Activities
}

\section{Chao-Min Wang ${ }^{1}$, Yuan-Man Hsu ${ }^{2}$, Yun-Lian Jhan ${ }^{1}$, Shang-Jie Tsai ${ }^{1}$, Shi-Xun Lin ${ }^{1}$, Chiu-Hsian $\mathrm{Su}^{2}$ and Chang-Hung Chou ${ }^{1,2,3, *}$}

1 Research Center for Biodiversity, China Medical University, Taichung 40402, Taiwan; E-Mails: wangchaomin@mail.cmu.edu.tw (C.-M.W.); ah_giu@hotmail.com (Y.-L.J.); csungjay@yahoo.com.tw (S.-J.T.); flyalonewithme9147@gmail.com (S.-X.L.)

2 Department of Biological Science and Technology, China Medical University, Taichung 40402, Taiwan; E-Mails: yuanmh@mail.cmu.edu.tw (Y.-M.H.); adaga0806@hotmail.com (C.-H.S.)

3 Department of Life Sciences, National Cheng Kung University, Tainan 701, Taiwan

* Author to whom correspondence should be addressed; E-Mail: choumasa@mail.cmu.edu.tw; Tel.: +886-422-053-366 (ext. 1633); Fax: +886-422-071-500.

Academic Editor: Isabel Ferreira

Received: 4 June 2015 / Accepted: 13 July 2015 / Published: 15 July 2015

\begin{abstract}
Rhododendron formosanum is an endemic species distributed in the central mountains of Taiwan. In this study, the biological activities of major procyanidins isolated from the leaf extract of $R$. formosanum were investigated. Four compounds, including two procyanidin dimers, procyanidin A1 (1) and B3 (2), and two procyanidin trimmers, procyanidin C4 (4) and cinnamtannin D1 (5), were isolated and identified on the basis of spectroscopic data. The structure of a new procyanidin dimer, rhodonidin A (3), was elucidated by 2D-NMR, CD spectrum and MS. The procyanidin trimmers and rhodonidin A are reported for the first time in Ericaceae. The biological activities of these procyanidins were evaluated using anti-bacterial and anti-oxidative assays. Only the new compound 3 demonstrated strong anti-bacterial activity against Staphylococcus aureus at an MIC value of $4 \mu \mathrm{g} / \mathrm{mL}$. All compounds showed pronounced antioxidant activities and the activities are enhanced as the amount of $\mathrm{OH}$ groups in procyanidins increased. In conclusion, the pleiotropic effects of procyanidins isolated from the leaves of $R$. formosanum can be a source of promising compounds for the development of future pharmacological applications.
\end{abstract}


Keywords: procyanidin A1; procyanidin B3; rhodonidin A; procyanidin C4; cinnamtannin D1; anti-bacterial; antioxidant

\section{Introduction}

Procyanidins are widely distributed throughout the plant kingdom. The evidences linked procyanidins with organoleptic characteristics, plant defense mechanisms, and potential health benefits were reported [1-3]. Among plant secondary metabolites, procyanidins are most liable to oxidation and their activity is closely related to plant defense systems against oxidative stress. Moreover, reports of several assays in vitro demonstrate potential interactions with biological functions, including antimicrobial [4], anti-proliferation [5], enzyme inhibiting [6], antioxidant, and radical-scavenging properties [1,2]. Typical condensed procyanidins exist as oligomers containing from two to five or six catechin or epicatechin units and as more condensed polymers. However, the structures of procyanidins, particularly larger polymeric procyanidins, are poorly understood.

Rhododendron formosanum is an endemic species distributed in the central mountains of Taiwan at elevations from $1500 \mathrm{~m}$ to $2500 \mathrm{~m}$. Previously, 18 hydrophobic compounds and two isomeric epoxysitosterols have been isolated and their allelopathic activities were also evaluated $[7,8]$. Recently, the anti-lung cancer activity of the pentacyclic triterpenoids isolated from $R$. formosanum was reported [9]. Moreover, the hydrophilic compounds responsible for allelopathic phenomenon were also identified by HPLC methods and the major chemical components of the leaves extract of $R$. formosanum were identified as (-)-catechin [10]. Catechin was further transformed into protocatechuic acid in the soil by microbes in the rhizosphere [11].The successful stabilization of $R$. formosanum is due to the synergistic phytotoxic effects of protocatechuic acid and (-)-catechin. Although the major chemicals in the leaves of $R$. formosanum have been investigated prominently, the structures of condensed procyanidins containing catechins or epicatechins units are still unknown.

The aim of this study was to isolate and elucidate the structure of procyanidins from the leaf extract of $R$. formosanum. The biological activities, including antibacterial and antioxidative activities, were also examined.

\section{Results and Discussion}

\subsection{Identification of Isolated Procyanidins}

Chemical structures of compounds 1-5 were illustrated in Figure 1. The ESI-MS of compound $\mathbf{1}$ recorded in negative-ion modes exhibited a deprotonated ion $[\mathrm{M}-\mathrm{H}]^{-}$at $\mathrm{m} / \mathrm{z} 575.1$, indicating molecular formulas of $\mathrm{C}_{30} \mathrm{H}_{24} \mathrm{O}_{12}$. The presence of the isolated $\mathrm{AB}$ coupling system at $\delta_{\mathrm{H}} 4.06(\mathrm{~d}, J=4.2 \mathrm{~Hz}$, $\mathrm{H}-3$ ), 4.23 (d, $J=3.6 \mathrm{~Hz}, \mathrm{H}-4$ ), the meta-coupled doublets at 5.95, 6.06 (each d, $J=2.4 \mathrm{~Hz}, \mathrm{H}-6, \mathrm{H}-8$ ), a residual one aromatic proton singlet at $\delta_{\mathrm{H}} 6.08$ (s, H- $\left.6^{\prime}\right)$, and two AMX systems in the aromatic region $\left(\delta_{\mathrm{H}} 6.5-7.5\right)$ due to rings $\mathrm{B}$ and $\mathrm{E}$ confirmed the A-type procyanidin. This doubly linked dimeric structure was also supported by the one acetal carbon at $\delta_{\mathrm{C}} 100.3$ in its ${ }^{13} \mathrm{C}-\mathrm{NMR}$ spectrum. A large value of $8-10 \mathrm{~Hz}$ for $J_{2,3}$ indicates a catechin unit (2,3-trans), and a small value of $2 \mathrm{~Hz}$ or a broad singlet 
indicates an epicatechin unit (2,3-cis). The signal widths and observable couplings $J_{2,3}$ and $J_{3,4}$ in 1 indicated the presence of epicatechin and catechin units. In addition, two flavanol units of A-type procyanidins must possess either $(2 \alpha, 4 \alpha)$ or $(2 \beta, 4 \beta)$ double interflavanyl bonds. The positive Cotton effect at 220-250 nm (Figure 2) of CD spectrum of compound 1 allowed assignment of absolute configuration of C-4 as $R[12,13]$, thus deciding the $2 \beta, 4 \beta$-configuration for compound 1 . Comparison of the ${ }^{1} \mathrm{H}$ - and ${ }^{13} \mathrm{C}-\mathrm{NMR}$ spectroscopic data with the literature established compound $\mathbf{1}$ as procyanidin $\mathrm{A} 1$ (Figure 1), previously isolated from peanut skins [14].

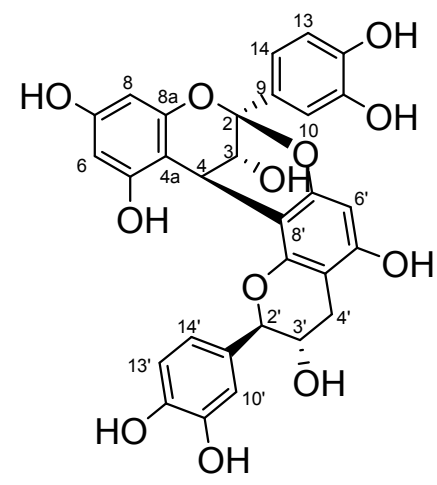

1<smiles>Oc1cc(O)c2c(c1)O[C@H](c1ccc(O)c(O)c1)C[C]2c1c(O)cc(O)c2c1O[C@H](c1ccc(O)c(O)c1)[C@H](O)[C@H]2c1c(O)cc(O)c2c1O[C@H](c1ccc(O)c(O)c1)[C@H](O)C2</smiles>

4<smiles>Oc1cc(O)c2c(c1)O[C@H](c1ccc(O)c(O)c1)[C@H](O)[C@H]2c1c(O)cc(O)c2c1O[C@H](c1ccc(O)c(O)c1)[C@H](O)C2</smiles>

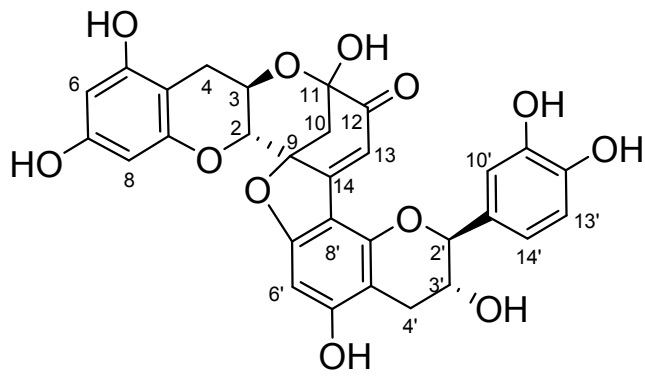

3

2

Figure 1. Chemical structures of compounds 1-5.

Compound 2 showed a molecular ion with $\mathrm{m} / \mathrm{z} 577.1$ in negative-ion modes, indicating that it was a B-type procyanidin dimer. Two AMX systems in the aromatic region $\left(\delta_{\mathrm{H}} 5.8-6.9\right)$ with large coupling constants in the region of $\delta_{\mathrm{H}} 4.5-3.7(\mathrm{H}-2 / \mathrm{H}-3 / \mathrm{H}-4)$ and the ${ }^{13} \mathrm{C}-\mathrm{NMR}$ spectrum of two carbon signals at 82.4 and 83.9 corresponding to $\mathrm{C} 2$ of $\mathrm{C}$ and $\mathrm{F}$ rings, two catechin units can be identified. The position of the interflavan bond was determined by HMBC data. CD measurements revealed a negative Cotton effect in the diagnostic wavelength region (220-240 nm), reflecting $\alpha$-orientation of the 4-flavanyl substituents (Figure 2). Because of rotational and heterocyclic ring conformational heterogeneity in dimeric procyanidins, the proton NMR spectrum of compound $\mathbf{2}$ exhibited two distinct sets of resonances showing the presence of two rotamers in an approximate 2:1 ratio. Comparison of the ${ }^{1} \mathrm{H}-$ and ${ }^{13} \mathrm{C}-\mathrm{NMR}$ spectroscopic data with the literature established compound 2 as procyanidin B3 (Figure 1) [15]. 

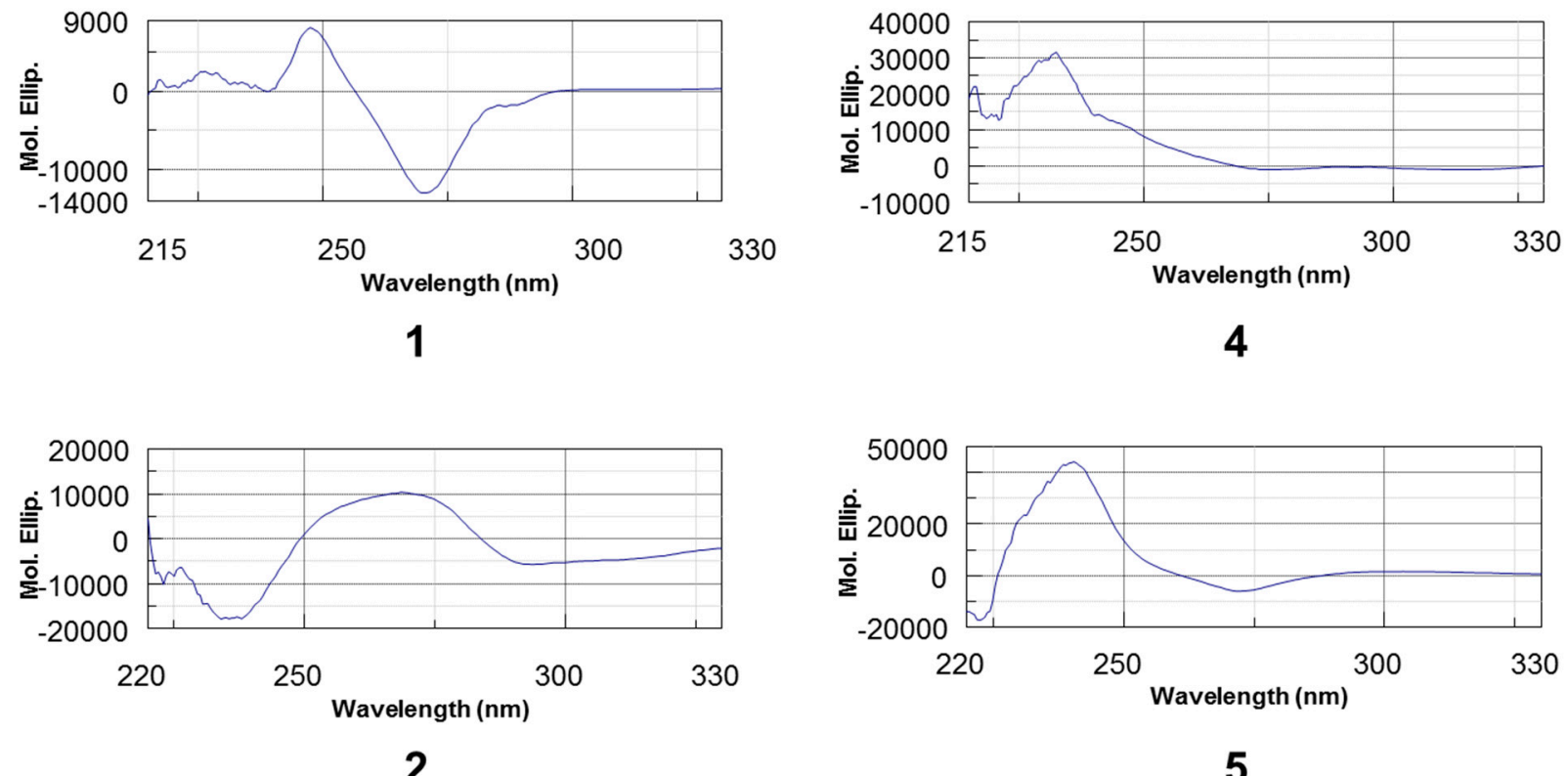

2
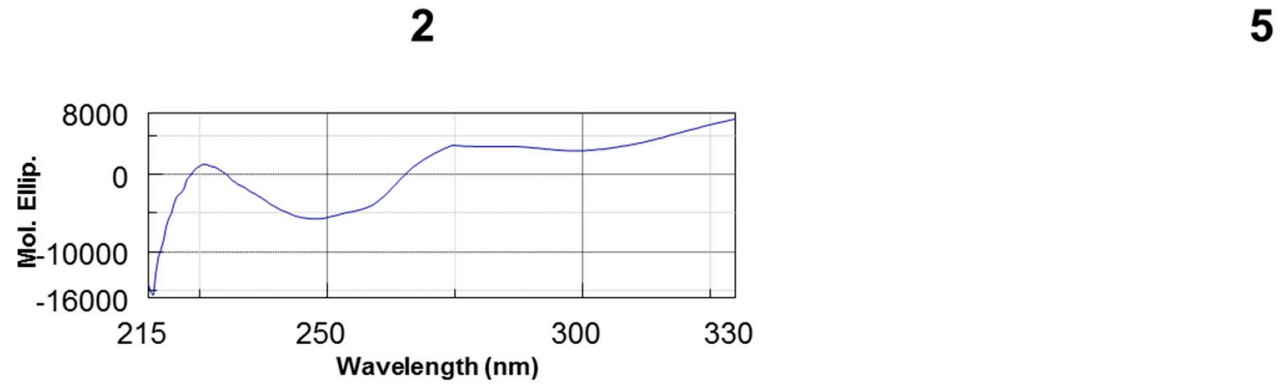

3

Figure 2. CD spectrum of compounds 1-5.

The HRESI-MS of compound 3 in negative-ion modes showed a deprotonated ion $[\mathrm{M}-\mathrm{H}]^{-}$at $\mathrm{m} / \mathrm{z}$ 575.1192 (Figure S2), indicating molecular formulas of $\mathrm{C}_{30} \mathrm{H}_{23} \mathrm{O}_{12}$ (575.1195). The ${ }^{1} \mathrm{H}-\mathrm{NMR}$ spectrum of compound 3 revealed two $\mathrm{AB}$ coupling systems attributable to H-3 atoms (3.98, m; 4.11, m), along with the ${ }^{13} \mathrm{C}-\mathrm{NMR}$ spectrum of two carbon signals at 79.5 and 83.4 corresponding to $\mathrm{C}-2$ of $\mathrm{C}$ and $\mathrm{F}$ rings (Table 1). The large value of $J_{2,3}$ and $J_{2^{\prime}, 3^{\prime}}$ coupling constant of 8.4 and $7.2 \mathrm{~Hz}$ confirmed a 2,3-trans configuration of two catechin units. The meta-coupled doublets at 5.90, 5.54 (each d, $J=3.2 \mathrm{~Hz}, \mathrm{H}-6$, $\mathrm{H}-8$ ), a residual one aromatic proton singlet at $\delta_{\mathrm{H}} 6.13$ (s, H- $6^{\prime}$ ), and one AMX systems in the aromatic region $\left(\delta_{\mathrm{H}} 6.74-6.85\right)$ due to rings E confirmed the linkage between two catechin units is from $\mathrm{B}$ to $\mathrm{D}$ ring. The ${ }^{1} \mathrm{H}-\mathrm{NMR}$ spectrum of compound $\mathbf{3}$ presented two singular features concerning the B-ring protons: two duplet $\left(\delta_{\mathrm{H}} 2.68\right.$ and 2.49$)$ with a large coupling constant $(J=11.4 \mathrm{~Hz})$ corresponding to the two aliphatic $\mathrm{H}-10$ protons and a singlet $(6.43 \mathrm{ppm})$ corresponding to the $\mathrm{H}-13$ proton involved in a conjugated system. The ${ }^{13} \mathrm{C}-\mathrm{NMR}$ spectrum of compound $\mathbf{3}$ exhibited four carbons presenting a chemical shift above $160 \mathrm{ppm}$ corresponding to carbons involved in the conjugated ketone systems of B and D rings. Based on the HMBC correlation (Figures S2-S4), C-11 and C-12 carbons were assigned by H-10 and $\mathrm{H}-13$ protons and their chemical shifts $\left(\delta_{\mathrm{C}}\right.$ at 95.3 and 194.1$)$ could be explained by their acetal and ketonic structure. 
Table 1. ${ }^{1} \mathrm{H}-\mathrm{NMR}(600 \mathrm{MHz})$ and ${ }^{13} \mathrm{C}-\mathrm{NMR}(150 \mathrm{MHz})$ spectroscopic data for compound 3 (in $\mathrm{CD}_{3} \mathrm{OD}, \delta$ in ppm, $J$ in $\mathrm{Hz}$ ).

\begin{tabular}{|c|c|c|c|}
\hline Units & Position & ${ }^{1} \mathbf{H}$ & ${ }^{13} \mathrm{C}$ \\
\hline \multirow{17}{*}{ I } & 2 & $3.97 \mathrm{~d}(8.4)$ & 79.5 \\
\hline & 3 & $3.98 \mathrm{~m}$ & 66.8 \\
\hline & $4 \beta$ & $2.94 \mathrm{dd}(5.4,14.4)$ & 27.8 \\
\hline & $4 \alpha$ & $2.52 \mathrm{dd}(9.0,14.4)$ & \\
\hline & $4 a$ & & 100.4 \\
\hline & 5 & & 157.6 \\
\hline & 6 & $5.90(3.2)$ & 97.0 \\
\hline & 7 & & 157.9 \\
\hline & 8 & $5.54(3.3)$ & 95.8 \\
\hline & $8 \mathrm{a}$ & & 156.3 \\
\hline & 9 & & 89.8 \\
\hline & 10 & $2.68 \mathrm{~d}(11.4)$ & 45.9 \\
\hline & 10 & $2.49 \mathrm{~d}(11.4)$ & \\
\hline & 11 & & 95.3 \\
\hline & 12 & & 194.1 \\
\hline & 13 & $6.43 \mathrm{~s}$ & 112.8 \\
\hline & 14 & & 164.4 \\
\hline \multirow{16}{*}{ II } & $2^{\prime}$ & $4.92 \mathrm{~d}(7.2)$ & 83.4 \\
\hline & $3^{\prime}$ & $4.11 \mathrm{~m}$ & 67.8 \\
\hline & $4^{\prime} \beta$ & $2.86 \mathrm{dd}(4.8,16.2)$ & 28.3 \\
\hline & $4^{\prime} \alpha$ & $2.60 \mathrm{dd}(7.8,16.2)$ & \\
\hline & $4 a^{\prime}$ & & 103.9 \\
\hline & $5^{\prime}$ & & 166.2 \\
\hline & $6^{\prime}$ & $6.13 \mathrm{~s}$ & 90.9 \\
\hline & $7^{\prime}$ & & 168.0 \\
\hline & $8^{\prime}$ & & 105.6 \\
\hline & $8 a^{\prime}$ & & 155.1 \\
\hline & $9^{\prime}$ & & 131.2 \\
\hline & $10^{\prime}$ & $6.85 \mathrm{~d}(2.4)$ & 114.8 \\
\hline & $11^{\prime}$ & & 146.4 \\
\hline & $12^{\prime}$ & & 146.5 \\
\hline & $13^{\prime}$ & $6.79 \mathrm{~d}(8.4)$ & 116.3 \\
\hline & $14^{\prime}$ & $6.74 \mathrm{dd}(8.4,2.4)$ & 119.7 \\
\hline
\end{tabular}

The C-8' involvement in the interflavan lineage was construed from the HMBC correlations, which permitted us to assign the $\mathrm{C}-8 \mathrm{a}^{\prime}$ and the $\mathrm{C}-5^{\prime}$ carbon atoms. The observation of the HMBC correlation from $\mathrm{H}-13$ to $\mathrm{C}-8^{\prime}$ also confirmed the linkage between $\mathrm{C}-14$ and C-8' (Figure S2). In addition, IR spectrum at 1843 and $1714 \mathrm{~cm}^{-1}$ also confirmed the ketonoic structure of C-12 (Figure S5). According to the data of ${ }^{1} \mathrm{H}$ - and ${ }^{13} \mathrm{C}-\mathrm{NMR}$ (Table 1) and 2D NMR (HSQC, HMBC), compound 3 is similar to dehydrodicatechin A, a (+)-catechin derivative which had been obtained by enzymatic oxidation [16] and isolated from the roots of Rosa laevigata [17] and Quercus ilex [18]. However, the NOE correlation between H-2 and H-10' (Figure S6) indicated the 3D structure of 3 is a compact and not extended form. 
The three-dimensional structure of compound $\mathbf{3}$ was obtained using ChemBio3D software and the MM2 force field. In the compact form of (-)-catechin dimer, correlation peaks are observed between $\mathrm{H}-2$ and $\mathrm{H}-10^{\prime}, \mathrm{H}-10^{\prime}$ and $\mathrm{H}-13$, and $\mathrm{H}-2$ and $\mathrm{H}-13$, for which the interatomic distance measured on the minimized structure are $3.76 \AA, 2.98 \AA$, and $3.32 \AA$, respectively (Figure 3 ). In the extended structure of $(+)$-catechin dimer, the NOE correlation could not be observed because the interatomic distances are all over the detection limited (5 $\AA$ ). Moreover, circular dichroism is a powerful tool for establishing the absolute configuration of flavonoids and procyanidin. A positive Cotton effect at $280 \mathrm{~nm}$ indicated a $2 S$ configuration while the negative Cotton effects in the $240 \mathrm{~nm}$ region indicated $3 R$ absolute configurations, respectively (Figure 2) [19]. The $2 S, 3 R$ configuration was also suggested by the negative optical rotation of 3 . Taking the NOE interactions into consideration, the data of circular dichroism defined the (-)-catechin unit with $2 S$ and $3 R$ absolute configurations. Thus, the name of compound 3 is given as rhodonidin A (Figure 1).

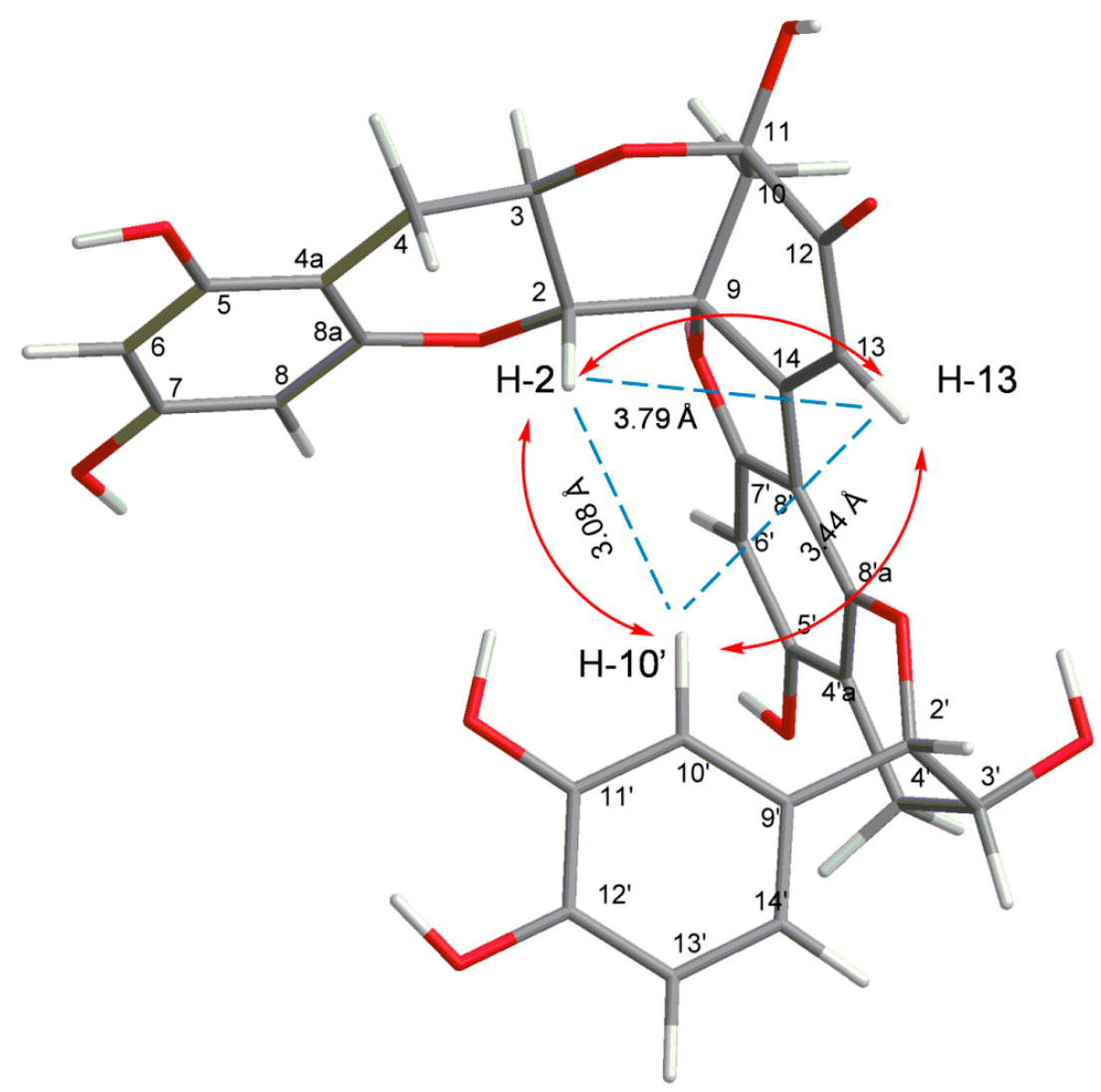

Figure 3. Selected NOESY correlations of compound 3.

The ESI-MS of compound $\mathbf{4}$ in the positive- and negative-ion modes exhibited a sodiated ion $[\mathrm{M}+\mathrm{H}+\mathrm{Na}]^{+}$at $m / z 890.1$ and deprotonated ion $[\mathrm{M}]^{-}$at $\mathrm{m} / z$ 866.2, indicating molecular formulas of $\mathrm{C}_{45} \mathrm{H}_{38} \mathrm{O}_{18}$, suggested a trimeric B-type procyanidin. The ${ }^{1} \mathrm{H}$ NMR spectrum of compound 4 revealed three proton signals $(3.98$, brs; $4.68, \mathrm{~m} ; 4.14, \mathrm{~m})$ attributable to the $\mathrm{H}-3$ atoms, along with a set of signals due to the $\mathrm{H}-2$ atoms of confirmed the one epicatechin with two catechin units. The ${ }^{13} \mathrm{C}-\mathrm{NMR}$ spectrum of compound 4 exhibited two C-2 signals at $\delta \mathrm{C} 82.0$ and 83.5 due to catechin units and one $\mathrm{C}-2$ signal at $\delta_{\mathrm{C}} 76.1$ consistent with an epicatechin unit. The spectroscopic data indicated the lineages between units were connected at position C-4 of unit I/II to C8 of unit II/III, which were confirmed 
by HMBC correlations between $\mathrm{H}-4$ and C-7', C-8', and C-9' and between H-4' and C-7"', C-8", and C-9", respectively. The CD spectrum of 4 showed a positive Cotton effect at 220-250 nm (Figure 2), demonstrated a $\beta$-orientation of 4-flavanyl linkage. According to the data of ${ }^{1} \mathrm{H}$ - and ${ }^{13} \mathrm{C}-\mathrm{NMR}$ and $2 \mathrm{D}$ NMR (HSQC, HMBC, COSY, NOESY), compound 4 is defined as procyanidin C4 [20].

The ESI-MS of compound $\mathbf{5}$ recorded in the positive- and negative-ion modes exhibited a sodiated ion $[\mathrm{M}+\mathrm{Na}]^{+}$at $m / z 887.1$ and deprotonated ion $[\mathrm{M}-\mathrm{H}]^{-}$at $m / z 863.1$, indicating molecular formulas of $\mathrm{C}_{45} \mathrm{H}_{36} \mathrm{O}_{18}$, suggested a triflavonoid moiety (trimeric A-type procyanidin) having only one $\mathrm{C}-\mathrm{O}-\mathrm{C}$ interflavanoid linkage in the structure. All ${ }^{1} \mathrm{H}$ - and ${ }^{13} \mathrm{C}-\mathrm{NMR}$ resonances of compound 5 were assigned by analysis of the 2D NMR (HSQC, HMBC, NOESY) data. In the ${ }^{1} \mathrm{H}-\mathrm{NMR}$ spectrum, the presence of the $\mathrm{AB}$ coupling system at $\delta_{\mathrm{H}} 3.45$ and 4.00 (each $\mathrm{d}, J=3.5 \mathrm{~Hz}$ ) also indicated an A-type unit in compound 5. This doubly linked structure was also supported from the one acetal carbon signal at $\delta_{\mathrm{C}} 100.0$ in the ${ }^{13} \mathrm{C}$-resonace. The NMR data of compound $\mathbf{5}$ in GHI moiety appearing at $\delta_{\mathrm{H}} 3.94(\mathrm{~d}$, $J=9 \mathrm{~Hz}), 3.67(\mathrm{~m}), 3.05(\mathrm{dd}, J=16.2,6.0)$, and $2.42(\mathrm{dd}, J=16.2,10.1)$ and $\delta_{\mathrm{C}} 83.2,70.0$, and 30.6 consistent with the terminal unit were identified as a catechin moiety. The ${ }^{1} \mathrm{H}$ and ${ }^{13} \mathrm{C}$ spectroscopic data of compound 5 in DEF moiety at $\delta_{\mathrm{H}} 5.51$ (brs), $4.06(\mathrm{~d}, J=1.8)$, and $\delta_{\mathrm{C}} 78.6,72.4$ suggested units II is epicatechins. Oligomeric procyanidins are generally linked from C-4 of one flavan unit to C-6 or C-8 of another, and when doubly connected it is often from C-2 of the upper unit to the hydroxyl group of the next unit at C-5 or C-7 position. The lineages between units were confirmed by HMBC correlations between $\mathrm{H}-4$ and $\mathrm{C}-7^{\prime}, \mathrm{C}-8^{\prime}$, and $\mathrm{C}-9^{\prime}$ and between $\mathrm{H}-4^{\prime}$ and $\mathrm{C}-7^{\prime \prime}, \mathrm{C}-8^{\prime \prime}$, and C-9", respectively. The CD spectrum of 5 showed a strong positive cotton effect at $220-250 \mathrm{~nm}$, demonstrated a $\beta$-orientation of 4-flavanyl linkage (Figure 2) [21]. Comparison of the ${ }^{1} \mathrm{H}$ - and ${ }^{13} \mathrm{C}-\mathrm{NMR}$ spectroscopic data with the literature established compound $\mathbf{5}$ as cinnamtannin D1 (Figure 1), previously isolated from Cinnamomum cassia [22], the leaves of Machilus philippinensis [21] and the bark of Parameria laevigata [23].

\subsection{Antibacterial Activity}

As shown in Table 2, the antibacterial activities of compounds 1-5 were tested against eight bacterial pathogens by minimum inhibitory concentration (MIC) or minimum bactericidal concentration (MBC) methods. Only procyanidins dimer (compound 1-3) displayed antibacterial activities against $S$. aureus. None of the procyanidins trimer showed pronounced antibacterial activities against all tested pathogens. In addition, only compound $\mathbf{1}$ demonstrated medium antimicrobial activities against $L$. monocytogenes and $B$. cereus. None of the bactericidal activities of isolated compounds against $H$. pylori were observed in this study.

Previous studies revealed a moderate antibacterial activity for certain procyanidins against Streptococcus pyogenes, Bacillus cereus, Klebsiella pneumoniae, and Proteus vulgaris at concentrations $<100 \mu \mathrm{g} / \mathrm{mL}$ [24]. The determination of MIC against $S$. aureus gave a value of $100 \mu \mathrm{g} / \mathrm{mL}$ for

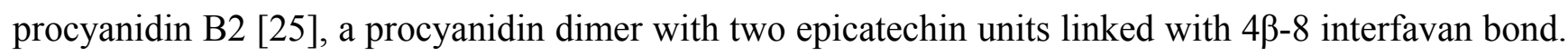
In this study, procyanidin A1 (1) and B3 (3) generated anti gram-positive bacteria activities at MIC values of $64 \mu \mathrm{g} / \mathrm{mL}$. All these results indicated procyanidin dimers displayed moderate antimicrobial activity against certain pathogens. Structure modification of procyanidins, such as rhodonidin A (3), may increase the antibacterial ability against $S$. aureus. In Asia, S. aureus is the leading cause of food-born 
pathogen. Thus, assessing potential antibacterial agent, such as rhodonidin A, and its antibacterial mechanism against $S$. aureus is a hot area of investigation.

Table 2. The minimum inhibitory concentration $(\mu \mathrm{g} / \mathrm{mL})$ of antibiotics and natural procyanidins for different bacterial pathogens.

\begin{tabular}{|c|c|c|c|c|c|c|c|c|}
\hline \multirow{3}{*}{ Pathogens } & \multicolumn{8}{|c|}{ Minimum Inhibitory Concentration $(\mu \mathrm{g} / \mathrm{mL})$} \\
\hline & \multicolumn{8}{|c|}{ Antibiotics and Procyanidins } \\
\hline & Ap * & Tet & Met & 1 & 2 & 3 & 4 & 5 \\
\hline Staphylococcus aureus & 16 & 8 & ${ }^{+}$N.D. & 64 & 64 & 4 & $>128$ & $>128$ \\
\hline Enterococcus faecalis & 2 & 4 & N.D. & $>128$ & $>128$ & $>128$ & $>128$ & $>128$ \\
\hline Listeria monocytogenes & 1 & 2 & N.D. & 64 & $>128$ & $>128$ & $>128$ & $>128$ \\
\hline Bacillus cereus & 128 & 4 & N.D. & 64 & $>128$ & $>128$ & $>128$ & $>128$ \\
\hline Escherichia coli & 4 & 0.5 & N.D. & $>128$ & $>128$ & $>128$ & $>128$ & $>128$ \\
\hline Salmonella enterica & 1 & 8 & N.D. & $>128$ & $>128$ & $>128$ & $>128$ & $>128$ \\
\hline Pseudomonas aeruginosa & 512 & 32 & N.D. & $>128$ & $>128$ & $>128$ & $>128$ & $>128$ \\
\hline Helicobacter pylori $* *$ & N.D. & N.D. & 2 & $>256$ & $>256$ & $>256$ & $>256$ & $>256$ \\
\hline
\end{tabular}

* Ap: ampicillin; Tet: tetracycline; Met: metronidazole; 1: procyanidin A1; 2: procyanidin B3; 3: rhodonidin A; 4: procyanidin $\mathrm{C} 4 ; \mathbf{5}$ : cinnamtannin D1; ** H. pylori was tested by minimum bactericidal concentration method. ${ }^{+}$N.D.: not determined.

\subsection{Antioxidative Activity}

The antioxidant activities of the isolated procyanidins were measured using the DPPH free radical-scavenging assay and CUPric reducing antioxidant capacity (CUPRAC) method. The results from the DPPH ( $\mathrm{IC}_{50}$ ) method for the standard trolox, (-)-catechin and compounds 1-5 isolated in this study showed values of 61.12, 27.07, 20.89, 8.55, 13.06, 6.26 and $3.29 \mu \mathrm{g} / \mathrm{mL}$, respectively (Table 3). Cinnamtannin D1 showed lowest $\mathrm{IC}_{50}$ value at $3.29 \mu \mathrm{g} /$ demonstrating the strongest free radical-scavenging activity in this study. The radical scavenging activity is enhanced as the amount of $\mathrm{OH}$ groups in procyanidins increased (Figure 4A). These observations were in line with the results reported previously [24,26]. Ricardo da Silva et al. stated that it was not the degree of polymerization, but the number of hydroxyl groups that was important for the radical scavenging activity.

Table 3. The antioxidant activities of the procyanidins from leaves of $R$. formosanum using the DPPH free radical-scavenging assay $\left(\mathrm{IC}_{50}, \mu \mathrm{M}\right)$ and CUPric reducing antioxidant capacity (CUPRAC) method (TEACs).

\begin{tabular}{ccccc}
\hline \multirow{2}{*}{ Compounds } & Total OH & $\begin{array}{c}\text { Average } \\
\text { Groups }\end{array}$ & OH/unit & \multicolumn{2}{c}{ Antioxidant Activity } \\
\cline { 4 - 5 } & 2 & 2 & 61.12 & 1.00 \\
Trolox & & & CC$_{50} / \mathbf{D P P H}(\boldsymbol{\mu g} / \mathbf{m L})$ & CUPRAC (TEACs) \\
(-)-Catechin & 5 & 5 & 27.07 & 2.74 \\
$\mathbf{1}$ & 9 & 4.5 & 20.89 & 1.75 \\
$\mathbf{2}$ & 10 & 5 & 8.55 & 4.87 \\
$\mathbf{3}$ & 7 & 3.5 & 13.06 & 1.96 \\
$\mathbf{4}$ & 15 & 5 & 6.26 & 3.48 \\
$\mathbf{5}$ & 14 & 4.7 & 3.29 & 2.93 \\
\hline
\end{tabular}


(A)

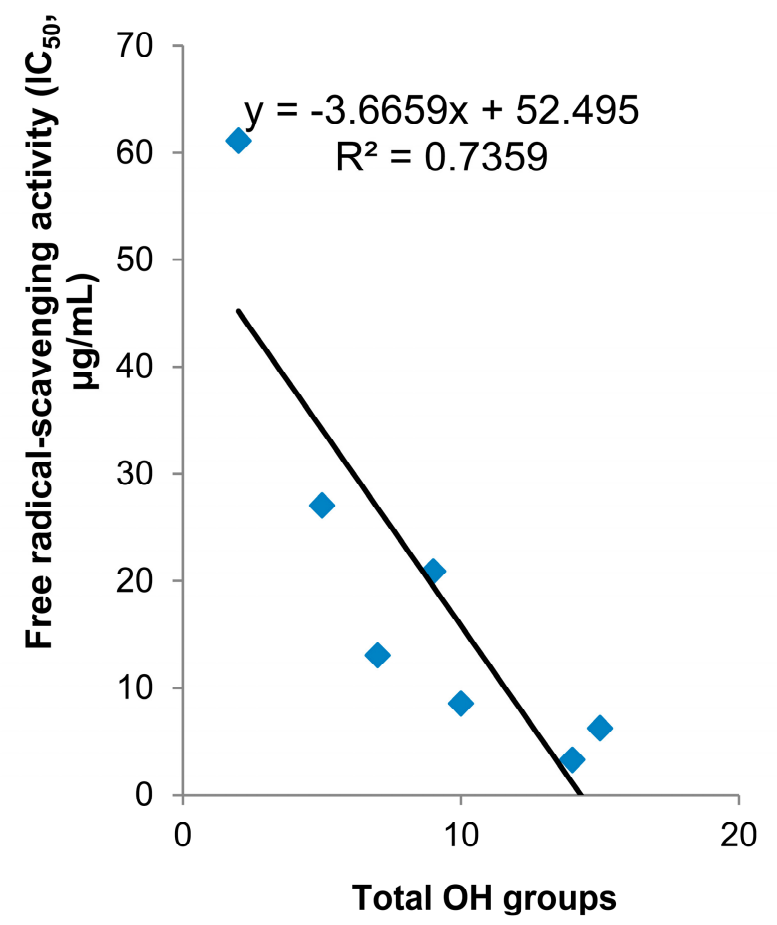

(B)

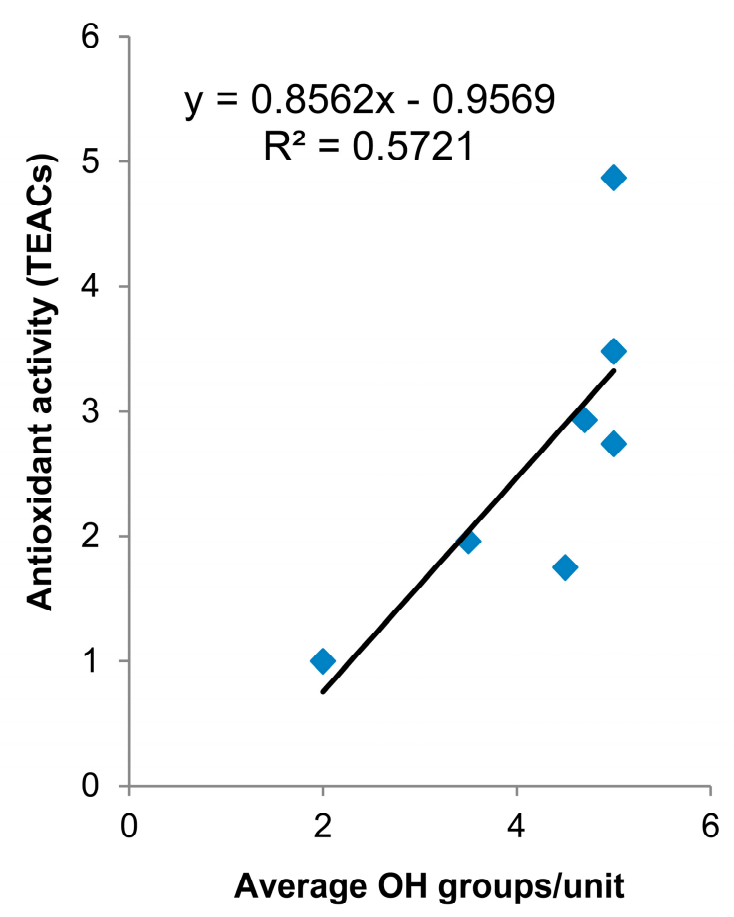

Figure 4. Correlations of total $\mathrm{OH}$ groups with free radical-scavenging activity (A) and average $\mathrm{OH}$ groups/unit with antioxidant activity (B).

In CUPRAC assay, trolox was used as standard chemical for antioxidant activity comparison. B-type procyanidins, such as procyanidin $\mathrm{B} 3$ and $\mathrm{C} 4$, displayed the highest values of antioxidant activities at 4.87 and 3.48 (TEACs), respectively. In contrast, A-type procyanidins A1 and rhodonidin A showed the lowest value at 1.75 and 1.96 (TEACs), respectively. Our results did not show a pronounced difference in antioxidant activity between total $\mathrm{OH}$ groups or the degree of polymerization (data not shown) but a significant increase between the average $\mathrm{OH}$ groups/unit with the antioxidant activity (Figure 4B).

\section{Experimental Section}

\subsection{General Information}

Optical rotations were obtained on a Jasco P-2000 digital polarimeter (Jasco, Tokyo, Japan). IR and UV spectra were recorded on Shimadzu IRAffinity 1S spectrometer (Shimadzu Corp., Tokyo, Japan) and Thermo MultiskanGo (Thermo Scientific, Lafayette, CO, USA), respectively. Circular Dichroism was obtained on a Jasco 715 spectrometer (Jasco, Tokyo, Japan). NMR spectra were obtained with a Varian Inova 600 NMR spectrometer (Angilent Tech., Palo Alto, CA, USA). ESI-MS spectra were performed on a Bruker Daltonics Esquire HCT spectrometer (Bruker Daltonics Inc., Billerica, MA, USA). HPLC analysis was carried out on a Hitachi L2130: column, Gemini C6-Phenyl, (5 $\mu \mathrm{m}, 10 \mathrm{~mm} \times$ $250 \mathrm{~mm}$ ); detector L2420 (Hitachi, Tokyo, Japan). Silica gel 60 (Merck, Darmstadt, Germany), Sephadex LH-20 (GE Healthcare, Uppsala, Sweden), XAD-2 (Sigma-Aldrich, St. Louis, MO, USA), XAD-7 (Sigma-Aldrich, St. Louis, MO, USA), Toyopearl HW-40F (Tosoh Bioscience, Tokyo, Japan), and RP-18 gel (LiChroprep, 40-63 $\mu \mathrm{m}$, Merck) were used for column chromatography. TLC was 
carried out on silica gel 60 (Merck, Germany) plates, and spots were visualized under UV light (254 or $356 \mathrm{~nm}$ ) or by spraying with $5 \% \mathrm{H}_{2} \mathrm{SO}_{4}$ in $95 \%$ EtOH followed by heating.

\subsection{Plant Material}

The leaves of Rhododendron formosanum were collected in April and July of 2010 from the study sites in Yuanzui mountain $\left(24^{\circ} 14^{\prime} 6.49^{\prime \prime} \mathrm{N}, 120^{\circ} 57^{\prime} 7.29^{\prime \prime} \mathrm{E}\right.$ at $1911 \mathrm{~m}$ a.s.1.) in Hopin township of Taichung County, Taiwan.

\subsection{Isolation and Identification of Procyanidins}

Five kilograms of air-dried leaves of $R$. formosanum was extracted with methanol thrice followed the standard extraction procedures [27]. The methanolic extract was concentrated to obtain $1540 \mathrm{~g}$ dry residue and then partitioned by dichloromethane (DCM), ethyl acetate (EtOAc) and $n$-butanol $(\mathrm{BuOH})$ with $\mathrm{H}_{2} \mathrm{O}$ to obtained portion of DCM (262 g), EtOAc (220 g), BuOH (423 g), and aqueous layer (420 g). The EtOAc portion was subjected to a silica gel column in gradient elution of mixture solvent composed of hexane-thyl and acetate-methanol and led to 31 fractions (EA-1-EA-31). Fraction EA-13 (10.8 g) was further subjected to a silica gel in gradient elution of ethyl acetate-methanol and led to 10 subfractions. In gradient elution of $\mathrm{MeOH}-\mathrm{H}_{2} \mathrm{O}(20 \%-40 \%)$, fraction EA-13-5 (1123.6 mg) was separated via RP-18 chromatography to obtain the compound $\mathbf{1}(139.4 \mathrm{mg})$. Compound 3 (23.6 mg) was further purified from fraction EA-13-6 (353 mg) by RP-18 chromatography (20\% MeOH). In elution of $100 \% \mathrm{MeOH}$, fraction 14-5 (1.44 g) was separated by Sephadex LH-20 to give nine subfractions. EA-14-5-7 (290.6 mg) was further subjected to RP-18 $(20 \% \mathrm{MeOH})$ and compound $2(22.6 \mathrm{mg})$ was purified by semi-prepared high-performance liquid chromatography (HPLC: column, Gemini C6-Phenyl, $5 \mu \mathrm{m}, 10 \mathrm{~mm} \times 250 \mathrm{~mm}$; solvent system: acetonitrile- $0.2 \%$ formic acid with gradient elution; flow rate: $1.5 \mathrm{~mL} / \mathrm{min}$; UV detection: $280 \mathrm{~nm}$ ). In gradient elution of $\mathrm{MeOH}-\mathrm{H}_{2} \mathrm{O}(60 \%-100 \%)$, fraction EA-17 (7.9 g) was separated via Amberlite XAD-2 gel column to obtain six subfractions. Fraction EA-17-2 (970.7 mg) was further fractionated by Toyopearl HW-40F chromatography in gradient elution of $\mathrm{MeOH}-\mathrm{H}_{2} \mathrm{O}$ (40\%-100\%) to give 14 subfractions. Finally, compound $5(214.5 \mathrm{mg})$ was isolated from the subfraction of EA-17-2-13. In addition, fraction EA-18 (12.34 g) was further purified through an Amberlite XAD-7 column (gradient elution of $\mathrm{MeOH}-\mathrm{H}_{2} \mathrm{O}, 0 \%-100 \%$ ), RP-18 column (gradient elution of $\mathrm{MeOH}-\mathrm{H}_{2} \mathrm{O}$, 40\%-100\%), and a Toyopearl HW-40F column, resulting in compound 4 (2.2 mg). Purification flow chart of procyanidins isolated from $R$. formosanum was illustrated as Figure 5. Purified compounds were subjected to spectroscopic identification by using ${ }^{1} \mathrm{H}-\mathrm{NMR}$ and ${ }^{13} \mathrm{C}-\mathrm{NMR}$ (Varian Inova 600) and ESI-MS (Bruker Daltonics Esquire HCT). The isolated compounds were identified by comparison of spectra data with literatures reported previously. The compound purity was further purified by high-performance liquid chromatography (HPLC: column, Gemini C6-Phenyl, $5 \mu \mathrm{m}, 4.6 \mathrm{~mm} \times 250 \mathrm{~mm}$; solvent system: acetonitrile- $0.2 \%$ formic acid with gradient elution; flow rate: $1 \mathrm{~mL} / \mathrm{min}$; UV detection: $280 \mathrm{~nm})$. The purity of isolated compound was over $95 \%$. 


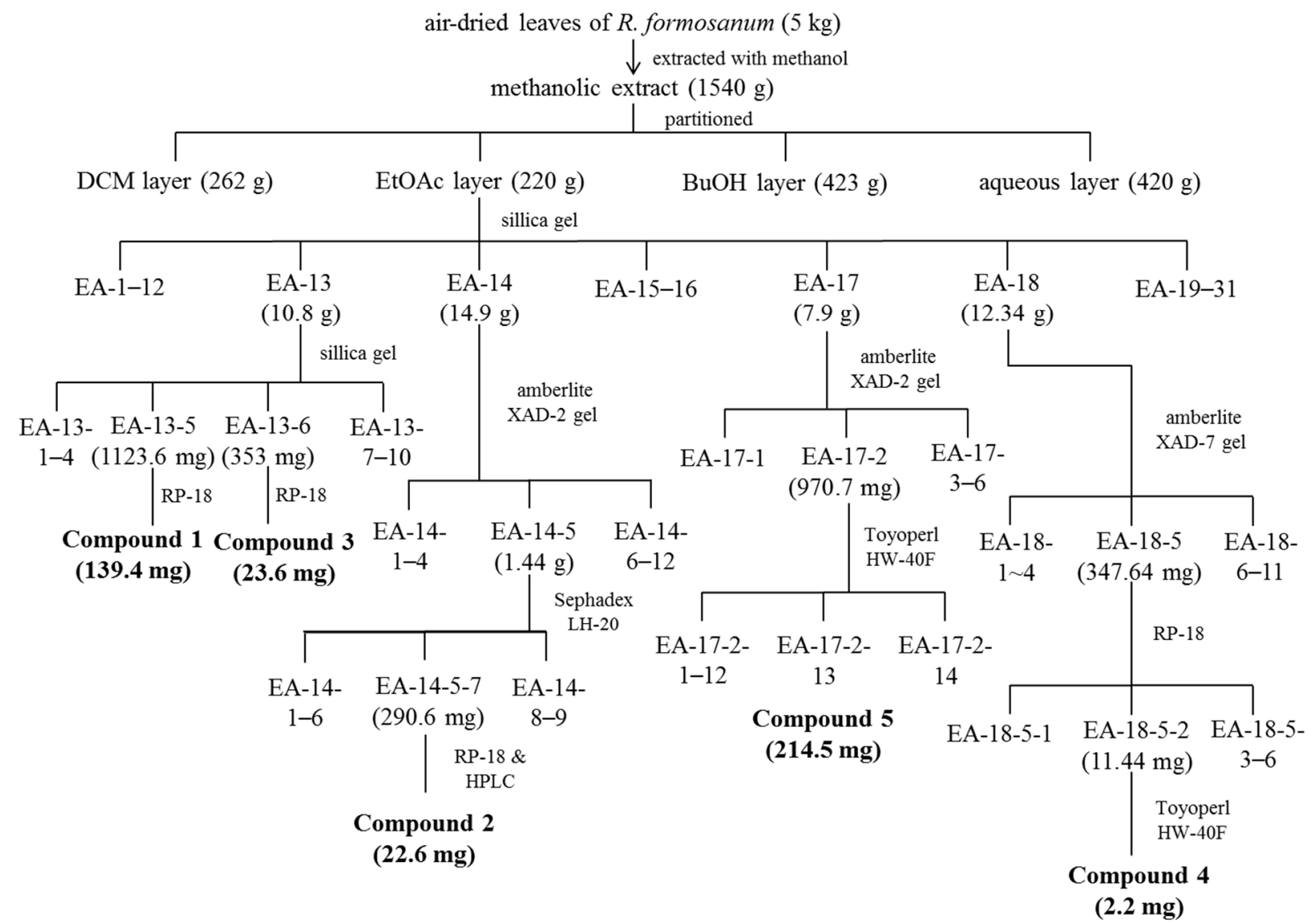

Figure 5. Purification flow chart of procyanidins isolated from $R$. formosanum.

Epicatechin- $(4 \beta \rightarrow 8 ; 2 \beta \rightarrow O \rightarrow 7)$-catechin (Procyanidin A1) (1). White amorphous powder; $[\alpha]_{D}^{25}$ $+18.4^{\circ}(c=0.1, \mathrm{MeOH}) ; \mathrm{UV}(\mathrm{MeOH}) \lambda_{\max }(\log \varepsilon) 280(2.32) \mathrm{nm} ; \mathrm{CD}(\mathrm{MeOH}, c=0.025) \mathrm{nm}(\varepsilon) 226$ (+0.72), 248 (+2.40), $270(-3.95)$; IR (KBr) cm $\mathrm{cm}^{-1}: 3394,1624,1521,1506,1473,1452,1373,1286$, 1178, 1143, 1116, 1066, 1008, 972, 879, 832, 783, 626; ESI-MS $m / z 575.1[\mathrm{M}-\mathrm{H}]^{-}$(Calcd for $\left.\mathrm{C}_{30} \mathrm{H}_{23} \mathrm{O}_{12}: 575.1\right) .{ }^{1} \mathrm{H}-\mathrm{NMR}\left(\mathrm{CD}_{3} \mathrm{OD}, 600 \mathrm{MHz}\right) \delta_{\mathrm{H}} 4.06(1 \mathrm{H}, \mathrm{d}, J=4.2 \mathrm{~Hz}, \mathrm{H}-3), 4.23(1 \mathrm{H}, \mathrm{d}, J=3.6 \mathrm{~Hz}$, $\mathrm{H}-4), 5.95(1 \mathrm{H}, \mathrm{d}, J=2.4 \mathrm{~Hz}, \mathrm{H}-6), 6.06(1 \mathrm{H}, \mathrm{d}, J=2.4 \mathrm{~Hz}, \mathrm{H}-8), 7.12(1 \mathrm{H}, \mathrm{d}, J=1.8 \mathrm{~Hz} \mathrm{H}-10), 6.81$ $(1 \mathrm{H}, \mathrm{d}, J=8.4 \mathrm{~Hz}, \mathrm{H}-13), 7.01(1 \mathrm{H}, \mathrm{dd}, J=8.4,2.4 \mathrm{~Hz}, \mathrm{H}-14), 4.72\left(1 \mathrm{H}, \mathrm{d}, J=7.8 \mathrm{~Hz} \mathrm{H}-2^{\prime}\right), 4.14$ $\left(1 \mathrm{H}, \mathrm{m}, \mathrm{H}-3^{\prime}\right), 2.57\left(1 \mathrm{H}, \mathrm{dd}, J=16.2,8.4 \mathrm{~Hz}, \mathrm{H}-4^{\prime} \alpha\right), 2.94\left(1 \mathrm{H}, \mathrm{dd}, J=16.2,5.4 \mathrm{~Hz}, \mathrm{H}-4^{\prime} \beta\right), 6.08(1 \mathrm{H}$, s, H-6'), $6.91\left(1 \mathrm{H}, \mathrm{s}, \mathrm{H}-10^{\prime}\right), 6.81\left(1 \mathrm{H}, \mathrm{s}, \mathrm{H}-13^{\prime}\right), 6.81\left(1 \mathrm{H}, \mathrm{d}, J=8.4 \mathrm{~Hz}, \mathrm{H}-14{ }^{\prime}\right) ;{ }^{13} \mathrm{C}-\mathrm{NMR}\left(\mathrm{CD}_{3} \mathrm{OD}\right.$, $150 \mathrm{MHz}$ ) $\delta_{\mathrm{C}} 100.3$ (C-2), 67.8 (C-3), 29.2 (C-4), 104.0 (C-4a), 156.8 (C-5), 98.1 (C-6), 158.1 (C-7), 96.5 (C-8), 154.2 (8a), 132.3 (C-9), 115.6 (C-10), 146.8 (C-11), 145.6 (C-12), 116.3 (C-13), 119.8 (C-14), 84.5 (C-2'), 68.1 (C-3'), 29.0 (C-4'), 103.1 (C-4'a), 156.1 ( C-5'), 96.5 (C-6'), 152.2 (C-7'), 106.8 (C-8'), 151.4 (C-8'a), 130.5 (C-9'), 115.7 (C-10'), 146.8 (C-11'), 146.3 (C-12'), 115.7 (C-13'), 120.7 (C-14').

Epicatechin- $(4 \alpha \rightarrow 8)$-catechin (Procyanidin B3) (2). White amorphous powder; $[\alpha]_{D}^{25}+14^{\circ}(c=0.1$, $\mathrm{MeOH})$; UV (MeOH) $\lambda_{\max }(\log \varepsilon) 208$ (2.74), $236(2.59) \mathrm{nm} ; \mathrm{CD}(\mathrm{MeOH}, c=0.025) \mathrm{nm}(\varepsilon) 214$ (+2.73), 234 (-0.74), 270 (0.43); IR (KBr) cm $\mathrm{cm}^{-1}$ : 3404, 1614, 1558, 1508, 1489, 1456, 1373, 1338, 1284, 1145, 1107, 1064, 817, 516, 424; ESI-MS: [M - H] $]^{-}, 577.1 \mathrm{~m} / \mathrm{z}$, (calcd for $\mathrm{C}_{30} \mathrm{H}_{25} \mathrm{O}_{12}: 577.1$ ); ${ }^{1} \mathrm{H}-\mathrm{NMR}\left(\mathrm{CD}_{3} \mathrm{OD}, 600 \mathrm{MHz}, 2: 1\right.$ mixture of rotational isomer), major isomer: $\delta_{\mathrm{H}} 4.25(1 \mathrm{H}, \mathrm{d}, J=10.2 \mathrm{~Hz}$, H-2), $4.36(1 \mathrm{H}, \mathrm{d}, J=9.6 \mathrm{~Hz}, \mathrm{H}-3), 4.41(1 \mathrm{H}, \mathrm{d}, J=8.4 \mathrm{~Hz}, \mathrm{H}-4), 5.88(1 \mathrm{H}, \mathrm{d}, J=2.4 \mathrm{~Hz}, \mathrm{H}-6), 5.78$ 
$(1 \mathrm{H}, \mathrm{d}, J=2.4 \mathrm{~Hz}, \mathrm{H}-8), 6.73(1 \mathrm{H}, \mathrm{d}, J=2.4 \mathrm{~Hz}, \mathrm{H}-10), 6.67(1 \mathrm{H}, \mathrm{d}, J=7.8 \mathrm{~Hz}, \mathrm{H}-13), 6.46(1 \mathrm{H}, \mathrm{dd}$, $J=8.4,1.8 \mathrm{~Hz}, \mathrm{H}-14), 4.54\left(1 \mathrm{H}, \mathrm{d}, J=7.2 \mathrm{~Hz}, \mathrm{H}-2^{\prime}\right), 3.79\left(1 \mathrm{H}, \mathrm{m} \mathrm{H}-3^{\prime}\right), 2.48$ (1H, dd, $J=16.2,7.8 \mathrm{~Hz}$, H-4' $\alpha), 2.76\left(1 \mathrm{H}, \mathrm{dd}, J=16.2,5.4 \mathrm{~Hz}, \mathrm{H}-4^{\prime} \beta\right), 6.07\left(1 \mathrm{H}, \mathrm{s}, \mathrm{H}-6^{\prime}\right), 6.59$ (1H, d, $\left.J=2.4 \mathrm{~Hz}, \mathrm{H}-10^{\prime}\right), 6.67$ $\left(1 \mathrm{H}, \mathrm{d}, J=8.4 \mathrm{~Hz}, \mathrm{H}-13^{\prime}\right), 6.25\left(1 \mathrm{H}, \mathrm{dd}, J=8.4,1.8 \mathrm{~Hz}, \mathrm{H}-14^{\prime}\right)$, minor isomer: $\delta \mathrm{H} 4.34(1 \mathrm{H}, \mathrm{d}$, $J=7.8 \mathrm{~Hz}, \mathrm{H}-2), 4.51(1 \mathrm{H}, \mathrm{d}, J=5.4 \mathrm{~Hz}, \mathrm{H}-3), 4.49(1 \mathrm{H}, \mathrm{d}, J=7.8 \mathrm{~Hz}, \mathrm{H}-4), 5.83(1 \mathrm{H}, \mathrm{d}, J=2.4 \mathrm{~Hz}, \mathrm{H}-6)$, $5.81(1 \mathrm{H}, \mathrm{d}, J=2.4 \mathrm{~Hz}, \mathrm{H}-8), 6.95(1 \mathrm{H}, \mathrm{d}, J=1.8 \mathrm{~Hz}, \mathrm{H}-10), 6.76(1 \mathrm{H}, \mathrm{d}, J=7.8 \mathrm{~Hz}, \mathrm{H}-13), 6.83(1 \mathrm{H}$, dd, $J=6.0,1.8 \mathrm{~Hz}, \mathrm{H}-14), 4.74\left(1 \mathrm{H}, \mathrm{d}, J=7.2 \mathrm{~Hz}, \mathrm{H}-2^{\prime}\right), 4.07\left(1 \mathrm{H}, \mathrm{m} \mathrm{H}-3^{\prime}\right), 2.58(1 \mathrm{H}, \mathrm{dd}, J=16.2$, $\left.7.8 \mathrm{~Hz}, \mathrm{H}-4^{\prime} \alpha\right), 2.82\left(1 \mathrm{H}, \mathrm{dd}, J=16.2,5.4 \mathrm{~Hz}, \mathrm{H}-4^{\prime} \beta\right), 5.94\left(1 \mathrm{H}, \mathrm{s}, \mathrm{H}-6^{\prime}\right), 6.95(1 \mathrm{H}, \mathrm{d}, J=1.8 \mathrm{~Hz}$, H-10') $6.76\left(1 \mathrm{H}, \mathrm{d}, J=8.4 \mathrm{~Hz}, \mathrm{H}-13^{\prime}\right), 6.82\left(1 \mathrm{H}, \mathrm{dd}, J=6.0,2.4 \mathrm{~Hz}, \mathrm{H}-14^{\prime}\right),{ }^{13} \mathrm{C}-\mathrm{NMR}\left(\mathrm{CD}_{3} \mathrm{OD}\right.$, $150 \mathrm{MHz}$ ), major isomer: $\delta_{\mathrm{C}} 83.9(\mathrm{C}-2), 73.6$ (C-3), $38.5(\mathrm{C}-4), 107.1(\mathrm{C}-4 \mathrm{a}), 157.1$ (C-5), $97.3(\mathrm{C}-6)$, 157.1 (C-7), 96.8 (C-8), 158.6 (C-8a), 132.6 (C-9), 116.4 (C-10), 145.6 (C-11), 146.0 (C-12), 116.1 (C-13), 120.5 (C-14), 82.4 (C-2'), 68.9 (C-3'), 28.7 (C-4'), 102.2 (C-4'a), 154.8 (C-5'), 96.0 (C-6'), 155.8 (C-7'), 108.1 (C-8'), 155.6 (C-8'a), 131.8 (C-9'), 115.5 (C-10'), 145.4 (C-11'), 145.7 (C-12'), 116.0 (C-13'), 119.8 (C-14'), minor isomer: $\delta_{\mathrm{C}} 84.0$ (C-2), 73.6 (C-3), 38.5 (C-4), 107.1 (C-4a), 157.2 (C-5), 97.5 (C-6), 157.4 (C-7), 96.2 (C-8), 158.6 (C-8a), 132.4 (C-9), 116.1 (C-10), 146.1 (C-11), 146.3 (C-12), 116.0 (C-13), 121.0 (C-14), 82.9 (C-2'), 68.5 (C-3'), 28.4 (C-4'), 100.4 (C-4'a), 154.9 (C-5'), 95.5 (C-6'), 155.7 (C-7'), 108.3 (C-8'), 155.6 (C-8'a), 132.1 (C-9'), 115.1 (C-10'), $146.1\left(\mathrm{C}-11^{\prime}\right), 146.3$ (C-12'), $115.9\left(\mathrm{C}-13^{\prime}\right), 120.1\left(\mathrm{C}-14^{\prime}\right)$.

Rhodonidin A (3). Yellew amorphous powder; $[\alpha]_{D}^{25}-13.2^{\circ}(c=0.1, \mathrm{MeOH}) ; \mathrm{UV}(\mathrm{MeOH}) \lambda_{\max }(\log \varepsilon)$ 216 (3.39), $278(2.72) \mathrm{nm}$; CD (MeOH, $c=0.01) \mathrm{nm}(\varepsilon) 216(-4.75), 248(-1.75), 275(+1.12)$; IR $(\mathrm{KBr}) \mathrm{cm}^{-1}: 3444,1843,1714,1643,1577,1558,1541,1519,1489,1456,1384,1338,1284,1249$, 1195, 1114, 1068, 1033, 815, 636, 455, 443; HRESI-MS: [M - H] $]^{-}, 575.1192 \mathrm{~m} / \mathrm{z}$, (calcd for $\mathrm{C}_{30} \mathrm{H}_{23} \mathrm{O}_{12}$ : 575.1195); ${ }^{1} \mathrm{H}-\mathrm{NMR}\left(\mathrm{CD}_{3} \mathrm{OD}, 600 \mathrm{MHz}\right) \delta_{\mathrm{H}} 3.97$ (1H, d, $\left.J=2.4 \mathrm{~Hz}, \mathrm{H}-2\right), 3.98$ (1H, m, H-3), 2.94 $(1 \mathrm{H}, \mathrm{dd}, J=14.45 .4 \mathrm{~Hz}, \mathrm{H}-4 \beta), 2.52(1 \mathrm{H}, \mathrm{dd}, J=14.49 .0 \mathrm{~Hz}, \mathrm{H}-4 \alpha), 5.90(1 \mathrm{H}, \mathrm{d}, J=3.2 \mathrm{~Hz}, \mathrm{H}-6)$, $5.54(1 \mathrm{H}, \mathrm{d}, J=3.3 \mathrm{~Hz}, \mathrm{H}-8), 2.68(1 \mathrm{H}, \mathrm{d}, J=11.4 \mathrm{~Hz}, \mathrm{H}-10 \beta), 2.49(1 \mathrm{H}, \mathrm{d}, J=11.4 \mathrm{~Hz}, \mathrm{H}-10 \alpha), 6.43$ $(1 \mathrm{H}, \mathrm{s}, \mathrm{H}-13), 4.92\left(1 \mathrm{H}, \mathrm{d}, J=7.2 \mathrm{~Hz}, \mathrm{H}-2^{\prime}\right), 4.11\left(1 \mathrm{H}, \mathrm{m}, \mathrm{H}-3^{\prime}\right), 2.86\left(1 \mathrm{H}, \mathrm{dd}, J=16.2,4.8 \mathrm{~Hz}, \mathrm{H}-4^{\prime} \beta\right)$, $2.60\left(1 \mathrm{H}, \mathrm{dd}, J=16.2,7.8 \mathrm{~Hz}, \mathrm{H}-4^{\prime} \alpha\right), 6.13\left(1 \mathrm{H}, \mathrm{s}, \mathrm{H}-6^{\prime}\right), 6.85\left(1 \mathrm{H}, \mathrm{d}, J=2.4 \mathrm{~Hz}, \mathrm{H}-10^{\prime}\right), 6.79(1 \mathrm{H}, \mathrm{d}$, $\left.J=8.4 \mathrm{~Hz}, \mathrm{H}-13^{\prime}\right), 6.74\left(1 \mathrm{H}, \mathrm{dd}, J=8.4,2.4 \mathrm{~Hz}, \mathrm{H}-14^{\prime}\right) ;{ }^{13} \mathrm{C}-\mathrm{NMR}\left(\mathrm{CD}_{3} \mathrm{OD}, 150 \mathrm{MHz}\right) \delta_{\mathrm{C}} 79.5(\mathrm{C}-2)$, 66.8 (C-3), 27.8 (C-4), 100.4 (C4a), 157.6 (d, C-5), 97.0 (C-6), 157.9 (C-7), 95.8 (C-8), 156.3 (C8a), 89.8 (C-9), 45.9 (C-10), 95.3 (C-11), 194.1 (C-12), 112.8 (C-13), 164.4 (C-14), 83.4 (C-2'), 67.8 (C-3'), 28.3 (C-4'), 103.9 (C-4'a), 166.2 (C-5'), 90.9 (C-6'), 168.0 (C-7'), 105.6 (C-8'), 155.1 (C-8'a), 131.2 (C-9'), $114.8\left(\mathrm{C}-10^{\prime}\right), 146.4$ (C-11'), 146.5 (C-12'), 116.3 (C-13'), 119.7 (C-14').

Epicatechin- $(4 \beta \rightarrow 8)$-catechin- $(4 \alpha \rightarrow 8)$-catechin (Procyanidin C4) (4). White amorphous powder; $[\alpha]_{D}^{25}$ $-15.7^{\circ}(c=0.1, \mathrm{MeOH}) ; \mathrm{UV}(\mathrm{MeOH}) \lambda_{\max }(\log \varepsilon) 230(3.58), 280(3.31) \mathrm{nm} ; \mathrm{CD}(\mathrm{MeOH}, c=0.017) \mathrm{nm}$ (ع) $216(+6.69), 232(+9.49), 274(-0.35), 312(-0.35)$; ESI-MS: $[\mathrm{M}]^{-}, 866.2 \mathrm{~m} / \mathrm{z},[\mathrm{M}+\mathrm{H}+\mathrm{Na}]^{+} 890.1$ $m / z$ (calcd for $\mathrm{C}_{45} \mathrm{H}_{38} \mathrm{O}_{18}$ : 866.2); ${ }^{1} \mathrm{H}-\mathrm{NMR}\left(\mathrm{CD}_{3} \mathrm{OD}, 600 \mathrm{MHz}\right) \delta_{\mathrm{H}} 5.24(1 \mathrm{H}, \mathrm{s}, \mathrm{H}-2), 3.98(1 \mathrm{H}$, brs, H-3), $4.75(1 \mathrm{H}, \mathrm{d}, J=1.2 \mathrm{~Hz}, \mathrm{H}-4), 5.84(2 \mathrm{H}, \mathrm{s}, \mathrm{H}-6, \mathrm{H}-8), 7.00$ (1H, d, $J=1.8 \mathrm{~Hz}, \mathrm{H}-10), 6.74$ (1H, d, $J=8.4 \mathrm{~Hz}, \mathrm{H}-13), 6.67$ (1H, dd, $J=8.4,1.8 \mathrm{~Hz}, \mathrm{H}-14), 4.48$ (1H, d, $\left.J=10.2 \mathrm{~Hz}, \mathrm{H}-2^{\prime}\right), 4.68$ (1H, m, H-3'), $4.71\left(1 \mathrm{H}, \mathrm{d}, J=7.2 \mathrm{~Hz}, \mathrm{H}-4^{\prime}\right), 5.90\left(1 \mathrm{H}, \mathrm{s}, \mathrm{H}-6^{\prime}\right), 7.01\left(1 \mathrm{H}, \mathrm{d}, J=1.8 \mathrm{~Hz}, \mathrm{H}-10^{\prime}\right), 6.81(1 \mathrm{H}, \mathrm{d}, J=8.4 \mathrm{~Hz}$, H-13'), 6.88 (1H, dd, $J=6.0,1.8$ Hz, H-14'), 4.14 (1H, m, H-3"), 2.68 (1H, dd, $J=16.8,5.4$ Hz, H-4" $\alpha$ ), 
$2.62\left(1 \mathrm{H}, \mathrm{dd}, J=16.8,6.0 \mathrm{~Hz}, \mathrm{H}-4^{\prime \prime} \beta\right), 5.97\left(1 \mathrm{H}, \mathrm{s}, \mathrm{H}-6^{\prime \prime}\right), 6.90\left(1 \mathrm{H}, \mathrm{brs}, \mathrm{H}-10^{\prime \prime}\right), 6.71(1 \mathrm{H}, \mathrm{d}, J=7.2 \mathrm{~Hz}$, $\left.\mathrm{H}-13^{\prime \prime}\right), 6.88\left(1 \mathrm{H}, \mathrm{d}, J=6.0,1.8 \mathrm{~Hz}, \mathrm{H}-14^{\prime \prime}\right) ;{ }^{13} \mathrm{C}-\mathrm{NMR}\left(\mathrm{CD}_{3} \mathrm{OD}, 150 \mathrm{MHz}\right) \delta_{\mathrm{c}} 77.3$ (C-2), 72.7 (C-3), 37.0 (C-4), 101.2 (C-4a), 157.3 (C-5), 97.7 (C-6), 158.4 (C-7), 96.1 (C-8), 157.1 (C-8a), 132.9 (C-9), 115.0 (C-10), 145.2 (C-11), 145.8 (C-12), 116.1 (C-13), 118.7 (C-14), 83.5 (C-2'), 73.0 (C-3'), 39.0 (C-4'), 107.2 (C-4'a), 156.4 (C-5'), 97.2 (C-6'), 156.0 (C-7'), 107.7 (C-8'), 156.9 (C-8'a), 132.1 (C-9'),

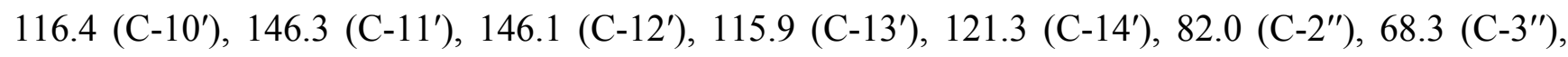
26.8 (C-4"), 100.6 (C-4"a), 155.7 (C-5"), 99.4 (C-6"), 155.6 (C-7"), 107.3 (C-8"), 155.0 (C-8"a), 132.6 $\left(\mathrm{C}-9^{\prime \prime}\right), 114.5\left(\mathrm{C}-10^{\prime \prime}\right), 145.8\left(\mathrm{C}-11^{\prime \prime}\right), 146.5\left(\mathrm{C}-12^{\prime \prime}\right), 116.1\left(\mathrm{C}-13^{\prime \prime}\right), 119.4\left(\mathrm{C}-14^{\prime \prime}\right)$.

Epicatechin- $(4 \beta \rightarrow 8 ; 2 \beta \rightarrow O \rightarrow 7)$-epicatechin- $(4 \beta \rightarrow 8)$-catechin (Cinnamtannin D1) (5). White amorphous powder; $[\alpha]_{D}^{25}+34.5^{\circ}(c=0.1, \mathrm{MeOH}) ; \mathrm{UV}(\mathrm{MeOH}) \lambda_{\max }(\log \varepsilon) 230(3.56), 243$ (3.57), 280 (3.45) nm; $\mathrm{CD}(\mathrm{MeOH}, c=0.01) \mathrm{nm}(\varepsilon) 222(-5.17), 241(+13.35), 272,(-1.8), 304(+0.49)$; IR $(\mathrm{KBr}) \mathrm{cm}^{-1}$ : $3383,1614,1558,1521,1508,1448,1373,1338,1284,1246,1211,1178,1143,1114,1064,1010,974$, 869, 819, 781, 451, 418; ESI-MS: $[\mathrm{M}-\mathrm{H}]^{-}, 863.1 \mathrm{~m} / \mathrm{z}$, $[\mathrm{M}+\mathrm{Na}]^{+} 887.1 \mathrm{~m} / \mathrm{z}$ (calcd for $\mathrm{C}_{45} \mathrm{H}_{36} \mathrm{O}_{18}$ : 864.1); ${ }^{1} \mathrm{H}-\mathrm{NMR}\left(\mathrm{CD}_{3} \mathrm{OD}, 600 \mathrm{MHz}\right) \delta_{\mathrm{H}} 3.46(1 \mathrm{H}, \mathrm{d}, J=3.6 \mathrm{~Hz}, \mathrm{H}-3), 4.00(1 \mathrm{H}, \mathrm{d}, J=3.6 \mathrm{~Hz}, \mathrm{H}-4)$, $5.94(1 \mathrm{H}, \mathrm{s}, \mathrm{H}-6), 6.01(1 \mathrm{H}, \mathrm{s}, \mathrm{H}-8), 7.09(1 \mathrm{H}, \mathrm{d}, J=1.8 \mathrm{~Hz}, \mathrm{H}-10), 6.85$ (1H, d, $J=8.4 \mathrm{~Hz}, \mathrm{H}-13)$, $6.95(1 \mathrm{H}, \mathrm{dd}, J=8.4,2.4 \mathrm{~Hz}, \mathrm{H}-14), 5.51\left(1 \mathrm{H}, \mathrm{brs}, \mathrm{H}-2^{\prime}\right), 4.06\left(1 \mathrm{H}, \mathrm{d}, J=1.8 \mathrm{~Hz}, \mathrm{H}-3^{\prime}\right), 4.53$ (1H, brs, H-4'), $5.84\left(1 \mathrm{H}, \mathrm{s}, \mathrm{H}-6^{\prime}\right), 7.23\left(1 \mathrm{H}, \mathrm{d}, J=1.8 \mathrm{~Hz}, \mathrm{H}-10^{\prime}\right), 6.84\left(1 \mathrm{H}, \mathrm{d}, J=8.4 \mathrm{~Hz}, \mathrm{H}-13^{\prime}\right), 7.09$ (1H, dd, $\left.J=6.0,1.8 \mathrm{~Hz}, \mathrm{H}-14^{\prime}\right), 3.95\left(1 \mathrm{H}, \mathrm{d}, J=9.0 \mathrm{~Hz}, \mathrm{H}-2^{\prime \prime}\right), 3.67\left(1 \mathrm{H}, \mathrm{m}, \mathrm{H}-3^{\prime \prime}\right), 3.05(1 \mathrm{H}, \mathrm{dd}, J=16.2$, $\left.6.0 \mathrm{~Hz}, \mathrm{H}-4^{\prime \prime} \alpha\right), 2.42\left(1 \mathrm{H}, \mathrm{dd}, J=16.2,10.2 \mathrm{~Hz}, \mathrm{H}-4^{\prime \prime} \beta\right), 6.10\left(1 \mathrm{H}, \mathrm{s}, \mathrm{H}-6^{\prime \prime}\right), 6.75(1 \mathrm{H}, \mathrm{d}, J=2.4 \mathrm{~Hz}$, H-10"), $6.75\left(1 \mathrm{H}, \mathrm{d}, J=8.4 \mathrm{~Hz}, \mathrm{H}-13^{\prime \prime}\right), 6.67\left(1 \mathrm{H}, \mathrm{d}, J=7.8,1.8 \mathrm{~Hz}, \mathrm{H}-14{ }^{\prime \prime}\right) ;{ }^{13} \mathrm{C}-\mathrm{NMR}\left(\mathrm{CD}_{3} \mathrm{OD}\right.$, $150 \mathrm{MHz}) \delta_{\mathrm{C}} 100.0$ (C-2), 67.1 (C-3), 28.8 (C-4), 104.9 (C-4a), 156.5 (C-5), 98.3 (C-6), 157.6 (C-7), 96.3 (C-8), 154.1 (C-8a), 132.4 (C-9), 115.7 (C-10), 145.4 (C-11), 146.6 (C-12), 116.2 (C-13), 120.0 (C-14), 78.6 (C-2'), 72.4 (C-3'), 38.2 (C-4'), 106.5 (C-4'a), 155.7 (C-5'), 95.8 (C-6'), 150.9 (C-7'), 106.2 (C-8'), 151.7 (C-8'a), $131.5\left(\mathrm{C}-9^{\prime}\right), 116.5$ (C-10'), 145.8 (C-11'), $146.2\left(\mathrm{C}-12^{\prime}\right), 116.0\left(\mathrm{C}-13^{\prime}\right)$, $121.0\left(\mathrm{C}-14^{\prime}\right), 83.2\left(\mathrm{C}-2^{\prime \prime}\right), 70.0\left(\mathrm{C}-3^{\prime \prime}\right), 30.6\left(\mathrm{C}-4^{\prime \prime}\right), 101.7$ (C-4"a), 155.3 (C-5"), 96.3 (C-6"), 155.5 (C-7"), 108.7 (C-8"), 155.3 (C-8"a), 132.6 (C-9"), 116.0 (C-10"), 145.7 (C-11"), 145.9 (C-12"), 115.8 $\left(\mathrm{C}-13^{\prime \prime}\right), 119.9\left(\mathrm{C}-14^{\prime \prime}\right)$.

\subsection{Total Antioxidant Capacity (TAC)}

Pure compounds were tested by using the CUPric Reducing Antioxidant Capacity (CUPRAC) method [28] according to the protocol of QuantiChrom Antioxidant Assay kit (Bioassay Systems, Hayward, CA, USA) [29]. These assays are based on the reduction of $\mathrm{Cu}^{2+}$ to $\mathrm{Cu}^{+}$by the combined action of all antioxidants (reducing agents) in a sample. The resulting $\mathrm{Cu}^{+}$specifically forms a colored complex with a dye agent (4,4'-dicarboxy-2,2'-biquinoline) and the color intensity at $570 \mathrm{~nm}$ is measured as TAC. Briefly, compounds were diluted with distilled water to produce solutions of $0.1,0.25,0.5$, and $1 \mathrm{mM}$ concentration. The reaction was initiated by the addition of $100 \mu \mathrm{L}$ mixture of copper sulfate and dye agent with $20 \mu \mathrm{L}$ of each compound solution. The absorbance at $570 \mathrm{~nm}$ was calculated for each concentration relative to a blank absorbance and was plotted as a function of concentration of standard Trolox. At least three independent determinations were performed. The antioxidant activities of purified compounds 1-5 are expressed as TEAC (Trolox Equivalent Antioxidant Activity) values in comparison 
with TEAC activity of reported reference compounds, catechin (Sigma-Aldrich, USA) and epicatechin (Sigma-Aldrich, USA). Trolox was employed at concentrations ranging from 10-1000 $\mu \mathrm{M}$ to construct a calibration curve. TEAC value is defined as the concentration of standard Trolox solution with equivalent activity to $1 \mathrm{mM}$ concentration solution of purified compound.

\subsection{Free Radical Scavenging Activity}

The free radical scavenging activities of purified compounds were determined according to previous report. Briefly, the reaction for scavenging DPPH radicals was carried out by adding $2 \mu \mathrm{L}$ sample to $198 \mu \mathrm{L} \mathrm{DPPH}$ solution $(100 \mu \mathrm{M})$ at $25^{\circ} \mathrm{C}$. The mixture was shaken vigorously and left to stand for $30 \mathrm{~min}$ in the dark before measuring the absorbance at $517 \mathrm{~nm}$ against a blank. For the radical scavenging activities of procyanidins, $\mathrm{EC}_{50}$ values were calculated as the concentrations $(\mu \mathrm{M})$ that inhibited $50 \%$ of the DPPH radicals in the reaction.

Scavenging ability $(\%)=\left[\left(\Delta \mathrm{A}_{517}\right.\right.$ of control $-\Delta \mathrm{A}_{517}$ of sample $) / \Delta \mathrm{A}_{517}$ of control $] \times 100$

For comparison purposes, standard antioxidant compound trolox (from $0.7815-100 \mu \mathrm{M}, \mathrm{R}^{2}=0.999$ ) was used as standard antioxidant compound.

\subsection{Antibacterial Activity}

Eight strains of microorganisms were used: Bacillus cereus (ATCC 9139), Enterococcus faecalis (ATCC 29212), Escherichia coli (ATCC 35150), Listeria monocytogenes (ATCC 7644), Pseudomonas aeruginosa (ATCC 27853), Salmonella enterica (ATCC 13311), Staphylococcus aureus (ATCC 43300), and Helicobacter pylori (ATCC 700392), which were employed to evaluate the antibacterial assay. Minimum inhibitory concentration (MIC) and minimum bactericidal concentration (MBC) were determined by the broth micro-dilution method according to the guidelines of the Clinical and Laboratory Standards Institute [30]. H. pylori was grown on blood agars under microaerophilic conditions at $37{ }^{\circ} \mathrm{C}$ for 48-72 $\mathrm{h}$ while other bacteria strains were cultured on nutrient agar (Difco, USA) and incubated at $37^{\circ} \mathrm{C}$ for $24 \mathrm{~h}$. Bacterial inoculums were prepared in normal saline and diluted to give a final density of $5 \times 10^{5} \mathrm{cfu} / \mathrm{mL}$. All compounds were dissolved in DMSO (Sigma, USA) and then in nutrient broth to reach a final concentration of $512 \mu \mathrm{g} / \mathrm{mL}$. Serial two-fold dilutions were made in a concentration range from $0.25-256 \mu \mathrm{g} / \mathrm{mL}$. The MIC and MBC were defined as the lowest concentration at which no visible growth occurred in comparison with antibiotics (ampicillin, tetracyclin and metronidazole) as a positive control. Tests were repeated three times for each compound.

\section{Conclusions}

Five compounds, including two procyanidin dimers, procyanidin A1 (1) and B3 (2), two procyanidin trimmers, procyanidin $\mathrm{C} 4$ (4) and cinnamtannin D1 (5), and one new procyanidin dimer, rhodonidin A (3), have been isolated from the leaves of $R$. formosanum. Compound $\mathbf{3}$ demonstrated strong antimicrobial activity against Staphylococcus aureus at MIC value of $4 \mu \mathrm{g} / \mathrm{mL}$. Compounds 1-5 also showed pronounced antioxidant activities. The pleiotropic effects of procyanidins isolated from the leaves of $R$. formosanum can be a source of promising compounds for the development of future pharmacological applications. 


\section{Supplementary Materials}

Supplementary materials can be accessed at: http:/www.mdpi.com/1420-3049/20/07/12787/s1.

\section{Acknowledgments}

This work was financially supported by research grants from the National Science Council (NSC 102-2811-B-039-005 and NSC 102-2313-B-039-001-MY3) and Ministry of Science and Technology (MOST 103-2811-B-039-020) in Taiwan awarded to C.-H.C. Additionally, Hep G2 2.2.15 cell line donated by P.-C. Chen (College of Medicine, National Taiwan University), CD instrument provided by Assoc. S.-C. Chou (Department of Biological Science and Technology, China Medical University) and IR data performed by F.-P. Chang (The Ph.D. Program for Cancer Biology and Drug Discovery, China Medical University) are greatly appreciated. We also express our gratefulness for the technical assistance with chemical data analyses from Proteomics Research Core Laboratory, Office of Research \& Development at China Medical University and Instrument Analysis Centers at the National Chung-Hsing University.

\section{Author Contributions}

C.-M.W., Y.-M.H. and C.-H.C conceived and designed the experiments; C.-M.W., Y.-L.J., S.-J.T., S.-X.L. and C.-H.S. performed the experiments; C.-M.W. analyzed the data; C.-H.C and Y.-M.H. contributed reagents/materials/analysis tools; C.-M.W. and C.-H.C. wrote the paper. All authors read and approved the final manuscript.

\section{Conflicts of Interest}

The authors declare no conflict of interest.

\section{References and Notes}

1. Maatta-Riihinen, K.R.; Kahkonen, M.P.; Torronen, A.R.; Heinonen, I.M. Catechins and procyanidins in berries of Vaccinium species and their antioxidant activity. J. Agric. Food Chem. 2005, 53, 8485-8491.

2. Fu, C.L.; Wang, H.Y.; Ng, W.L.; Song, L.X.; Huang, D.J. Antioxidant activity and proanthocyanidin profile of Selliguea feei rhizomes. Molecules 2013, 18, 4282-4292.

3. He, F.; Pan, Q.H.; Shi, Y.; Duan, C.Q. Biosynthesis and genetic regulation of proanthocyanidins in plants. Molecules 2008, 13, 2674-2703.

4. Zang, X.Y.; Shang, M.Y.; Xu, F.; Liang, J.; Wang, X.; Mikage, M.; Cai, S.Q. A-type proanthocyanidins from the stems of Ephedra sinica (Ephedraceae) and their antimicrobial activities. Molecules 2013, 18, 5172-5189.

5. Kresty, L.A.; Howell, A.B.; Baird, M. Cranberry proanthocyanidins mediate growth arrest of lung cancer cells through modulation of gene expression and rapid induction of apoptosis. Molecules 2011, 16, 2375-2390. 
6. Wang, H.Y.; Song, L.X.; Feng, S.B.; Liu, Y.C.; Zuo, G.; Lai, F.L.; He, G.Y.; Chen, M.J.; Huang, D.J. Characterization of proanthocyanidins in stems of Polygonum multiflorum thunb as strong starch hydrolase inhibitors. Molecules 2013, 18, 2255-2265.

7. Chou, S.C.; Krishna, V.; Chou, C.H. Hydrophobic Metabolites from Rhododendron formosanum and their Allelopathic Activities. Nat. Prod. Commun. 2009, 4, 1189-1192.

8. Krishna, V.; Chang, C.I.; Chou, C.H. Two isomeric epoxysitosterols from Rhododendron formosanum: ${ }^{1} \mathrm{H}$ - and ${ }^{13} \mathrm{C}-\mathrm{NMR}$ chemical shift assignments. Magn. Reson. Chem. 2006, 44, 817-819.

9. Way, T.D.; Tsai, S.J.; Wang, C.M.; Ho, C.T.; Chou, C.H. Chemical constituents of Rhododendron formosanum show pronounced growth inhibitory effect on non-small-cell lung carcinoma cells. J. Agric. Food Chem. 2014, 62, 875-884.

10. Chou, S.C.; Huang, C.H.; Hsu, T.W.; Wu, C.C.; Chou, C.H. Allelopathic potential of Rhododendron formosanum Hemsl in Taiwan. Allelopathy J. 2010, 25, 73-91.

11. Wang, C.M.; Li, T.C.; Jhan, Y.L.; Weng, J.H.; Chou, C.H. The impact of microbial biotransformation of catechin in enhancing the allelopathic effects of Rhododendron formosanum. PLOS ONE 2013, 8, e85162.

12. Botha, J.J.; Ferreira, D.; Roux, D.G. Condensed tannins-circular-dichroism method of assessing absolute-configuration at C-4 of 4-arylflavan-3-ols, and stereochemistry of their formation from flavan-3,4-diols. J. Chem. Soc. Chem. Comm. 1978, 698-700, doi:10.1039/C39780000698.

13. Barrett, M.W.; Klyne, W.; Scopes, P.M.; Fletcher, A.C.; Porter, L.J.; Haslam, E. Plant proanthocyanidins. Part 6. chiroptical studies. Part 95. Circular-Dichroism of procyanidins. J. Chem. Soc. Perkin Trans. 1 1979, 2375-2377, doi:10.1039/P19790002375.

14. Lou, H.X.; Yamazaki, Y.; Sasaki, T.; Uchida, M.; Tanaka, H.; Oka, S. A-type proanthocyanidins from peanut skins. Phytochemistry 1999, 51, 297-308.

15. Oizumi, Y.; Mohri, Y.; Hirota, M.; Makabe, H. Synthesis of procyanidin B3 and its anti-inflammatory activity. The effect of 4-alkoxy group of catechin electrophile in the $\mathrm{Yb}(\mathrm{OTf})(3)$-catalyzed condensation with catechin nucleophile. J. Org. Chem. 2010, 75, 4884- 4886.

16. Guyot, S.; Vercauteren, J.; Cheynier, V. Structural determination of colourless and yellow dimers resulting from $(+)$-catechin coupling catalysed by grape polyphenoloxidase. Phytochemistry 1996, 42, 1279-1288.

17. Yan, G.Q.; Li, S.P.; Hu, J.; Zhai, X.Y.; Ma, W.; Li, N.; Wang, K.J. Phenolic constituents from the roots of Rosa laevigata (Rosaceae). Biochem. Syst. Ecol. 2014, 52, $23-26$.

18. Karioti, A.; Bilia, A.R.; Gabbiani, C.; Messori, L.; Skaltsa, H. Proanthocyanidin glycosides from the leaves of Quercus ilex L. (Fagaceae). Tetrahedron Lett. 2009, 50, 1771-1776.

19. Slade, D.; Ferreira, D.; Marais, J.P.J. Circular dichroism, a powerful tool for the assessment of absolute configuration of flavonoids. Phytochemistry 2005, 66, 2177-2215.

20. Saito, A.; Doi, Y.; Tanaka, A.; Matsuura, N.; Ubukata, M.; Nakajima, N. Systematic synthesis of four epicatechin series procyanidin trimers and their inhibitory activity on the Maillard reaction and antioxidant activity. Bioorg. Med. Chem. 2004, 12, 4783-4790.

21. Lin, H.C.; Lee, S.S. Proanthocyanidins from the leaves of Machilus philippinensis. J. Nat. Prod. 2010, 73, 1375-1380. 
22. Killday, K.B.; Davey, M.H.; Glinski, J.A.; Duan, P.G.; Veluri, R.; Proni, G.; Daugherty, F.J.; Tempesta, M.S. Bioactive A-type proanthocyanidins from Cinnamomum cassia. J. Nat. Prod. 2011, 74, 1833-1841.

23. Kamiya, K.; Ohno, A.; Horii, Y.; Endang, H.; Umar, M.; Satake, T. A-type proanthocyanidins from the bark of Parameria laevigata. Heterocycles 2003, 60, 1697-1708.

24. De Bruyne, T.; Pieters, L.; Witvrouw, M.; de Clercq, E.; vanden Berghe, D.; Vlietinck, A.J. Biological evaluation of proanthocyanidin dimers and related polyphenols. J. Nat. Prod. 1999, 62, 954-958.

25. Ming, D.S.; Lopez, A.; Hillhouse, B.J.; French, C.J.; Hudson, J.B.; Towers, G.H.N. Bioactive constituents from Iryanthera megistophylla. J. Nat. Prod. 2002, 65, 1412-1416.

26. Ricardo-Da-Silva, J.M.; Darmon, N.; Fernandez, Y.; Mitjavila, S. Oxygen free-radical scavenger capacity in aqueous models of different procyanidins from grape seeds. J. Agric. Food Chem. 1991, 39, 1549-1552.

27. Wang, C.M.; Chen, H.T.; Li, T.C.; Weng, J.H.; Jhan, Y.L.; Lin, S.X.; Chou, C.H. The role of pentacyclic triterpenoids in the allelopathic effects of Alstonia scholaris. J. Chem. Ecol. 2014, 40, 90-98.

28. Ozyurek, M.; Guclu, K.; Apak, R. The main and modified CUPRAC methods of antioxidant measurement. TrAC Trend. Anal. Chem. 2011, 30, 652-664.

29. Prior, R.L.; Wu, X.L.; Schaich, K. Standardized methods for the determination of antioxidant capacity and phenolics in foods and dietary supplements. J. Agric. Food Chem. 2005, 53, 4290-4302.

30. CLSI. Methods for Dilution Antimicrobial Susceptibility Tests for Bacteria that Grow Aerobically, 10th ed.; Clinical and Laboratory Standards Institute: Wayne, PA, USA, 2015.

Sample Availability: Samples of the compounds 1, 2, and $\mathbf{5}$ are available from the authors.

(C) 2015 by the authors; licensee MDPI, Basel, Switzerland. This article is an open access article distributed under the terms and conditions of the Creative Commons Attribution license (http://creativecommons.org/licenses/by/4.0/). 